it is the duty of France to restore the preëminence of quality and he points out that the way towards this end is easy. In fact his suggestions are "to give to quality opportunity to manifest itself, do not hide it under a bushel, for men never refuse to recognize the intellectual or moral superiority which is pointed out to them; their natural sentiments of equality and justice, far from being shocked by this, are exalted thereby. The young people, in particular, regard themselves united with the comrade whom they have learnt to appreciate; far from being jealous of his success, they are happy with him."

These suggestions should be equally useful among us where the need of reform is even more evident than in France. Our great western state universities are doubtless especially in danger of being overwhelmed by judgments of quantity, in view of their very direct contact with the public. They present therefore unusually important centers for emphasis on quality, and for guarding against being absorbed in the work which admits of exhibition in attractive circulars presenting statistical data in regard to quantity. Public references to quality of work and to the deeper joys and compensations of intellectual life are especially needed in these institutions.

The very rapid growth of our educational institutions has naturally led to an abnormal interest in changes in quantity. It is so easy and harmless to speak of the increase in the material equipment. It is much more difficult and delicate to make clear that the intellectual advances made by the faculty have kept pace with these material advances, or that the moral and intellectual influences surrounding the students are better than they were in former years. These latter questions involve comparisons, and they frequently lead at first to differences of opinion. They are, however, the more important, and the foreign scholars who may be in our midst will judge us very largely by the way we deal with these questions of quality. It will be very unfortunate if we continue to impress these men as we seem to have impressed Professor Borel, especially since such impressions seem to represent only our superficial attitude, at least, as far as they relate to our intellectual and moral life.

G. A. MILLER

UNIVERSITY OF ILLINOIS

\section{FREDERIC WARD PUTNAM}

With Professor Putnam, who died on August 14, at the age of seventy-six years, the last of the three men has passed away who may well be called the founders of modern anthropology in America: Brinton, Powell and Putnam. Brinton in Philadelphia, with keen, analytic mind, full of imagination, with wide interests, opened up ever new fields and problems and stimulated through his personal influence the work of others and paved the way to the recognition of anthropology as a scientific study. Powell performed the great service of organizing the anthropological work of the government by founding the Bureau of Ethnology and providing in this manner the means for scientific research. With rare insight he selected an unusually gifted group of men around himself, and to their labors we owe the fundamental data on which modern American ethnology has been built up. Through the sheer force of his personality he impressed some of his fundamental philosophic views and some of his methods upon his collaborators not only in the Bureau of Ethnology, but in a much wider group of scientists that came under his influence, and gave in this manner to anthropological studies a definite direction that may still be recognized.

Professor Putnam's contributions were of another kind. Taught in the Agassiz school of independent search for facts, he took up anthropological studies with that enthusiastic worship of material data as the indispensable basis for inductive studies that has dominated his life and that, together with his skill as an organizer, have made him the most potent factor in the development of anthropological institutions all over the country. Owing to the trend of his mind, his interests centered in the objective, tangible sides of anthropology and, therefore, his chief contribution lies in the development of museum work. The search for well authenticated Indian material and his in- 
terest in biological problems led him to lay particular stress upon archeological evidence, and in this field he did his most noteworthy work.

The Peabody Museum of American Archeology and Ethnology is, perhaps more than anything else, a monument of his life work, for in it are manifested the varied phases of his many-sided interest in the history of mankind, as exhibited by man's handiwork and by the remains of the races of man. The osteological department, surpassed only by the old collections of the Army Medical Museum in Washington, the materials relating to the study of the antiquity of man in America which he pursued with unconquerable tenacity, the collections from the mound and village sites of Ohio, the ample and valuable material from Mexico and Central America, the old New England collections, archeological as well as ethnological, not to mention others, indicate the lines of his own scientific activities.

In one respect he revolutionized American museum methods. While it has been customary to enlarge collections by purchase, he inaugurated scientific expeditions, the prime object of which was the discovery of scientific facts that were sustained by the evidences of collections. Journeys for the purpose of collecting had been made before his time, but he had the courage to emphasize that in museum expeditions, as in other scientific work, the method must be determined not by the number of specimens likely to be secured, but by the objects of the inquiry. To him the museum was the storehouse in which the materials accumulated by scientific research were cared for, digested and made accessible to the student. His constant insistance on this point of view gave to his museum work special value.

The development of the Peabody Museum and his wide acquaintance among American men of science and among those interested in the advancement of science, brought it about that his capacity as an organizer was sought in other centers in which there was a growing interest in archeology and anthropology. It was he who laid the foundation to the Field
Museum of Natural History by organizing the Anthropological Department of the World's Columbian Exposition in Chicago. There he solved the difficult task of bringing together in a short time material illustrating prehistoric America as well as the primitive life of the historic American Indian. With this accumulation of material he combined scientific investigation that bore fruit in later times in the intensive work among Indian tribes carried on by a number of institutions. Some of the important archeological results of this period still await publication. Together with the treasures of the Peabody Museum and those of the Museums of Ohio they will elucidate a remarkable period in the history of early America, the thorough exploration of which was begun and carried along for years by Professor Putnam. Unfavorable conditions prevented the completion of this work that was always near to his heart. The opportunities offered by the World's Columbian Exposition enabled him also to advance the work of securing replicas of the monuments of Central America, a subject to which he devoted much of his time and energies.

At the close of the World's Fair he was called to New York to organize the anthropological work of the American Museum of Natural History, and here we find him introducing the same methods of development that had been so effective in building up the Peabody Museum as a center of scientific research. The field investigations of the New York Museum extended beyond the narrow limits of the North American continent and inaugurated a period of active scientific research.

His great success as an organizer brought it about that when the development of anthropological work, partly owing to his influence, was planned in the University of California, he was called upon to take a vigorous part in the formulation of plans for a museum and for the scientific work of the newly founded department of anthropology which followed much the same lines as those inaugurated by him in other institutions.

While these four large institutions had the benefit of the stimulus of his sustained per- 
sonal efforts, many others were helped by his advice and assistance.

Professor Putnam's influence has been great in still other ways. He succeeded in having anthropology recognized by Harvard University as a regular subject of instruction, with the result that an ever-increasing number of students became interested in this subject. His influence as a lecturer was, however, not as great as that of his personal contact with students. Through his sympathy with the personal interests of younger men, through his eagerness to help them along on the arduous path of the young scientist, he associated with himself a large number of young anthropologists who were filled with that enthusiasm for the unbiased collection of data that characterized his own work. The precedent set by Harvard University, and at the same time by Clark University, and Professor Putnam's unceasing agitation have done much to introduce anthropology as a subject of study in our universities. Men who have grown up as his students are now found in many American and Canadian institutions.

Professor Putnam's activities were not by any means confined to the field of his own researches, but he took a lively interest in the advancement of scientific work in the whole country. This quality, his genius as an organizer, and his sympathetic nature brought him into prominence in the work of the American Association for the Advancement of Science, of which he was for many years permanent secretary and which he made a most efficient means of promoting and extending the influence of science. It is a well-marked period of scientific development that his incumbency of the secretaryship represents: the extensive and gradual deepening of scientific interest. It covers the period preparatory to the specialization of more modern times that makes the American Association more an administrative clearing house of special scientific bodies than an agency that promotes popular interest and that gives to the young scientist the opportunity to gain his first laurels.

For several years Professor Putnam had been ailing, but his robust nature withstood vigorously the attacks of an insidious disease. On the occasion of his seventieth birthday his many friends gave expression to their warm feelings towards him by the publication of an anniversary volume containing contributions from almost all American anthropologists. His influence, that of a sane and sober scientist who values facts higher than fancies will be lasting, and we honor and love one who has helped to lay the foundations on which we are permitted to build.

\section{Columbia University}

Franz Boas

\section{PAUL EHRLICH'}

Pavl Ehrlich was a genius of the first order. While he was still a student of medicine, the problems presented by the affinity of lead for certain tissues attracted his attention. From speculating on the nature of this affinity, his interest grew to include protoplasmic affinities in general, and thus was determined the direction his genius should take.

Some of the notable results of his early investigations are discoveries in bacterial staining methods, which proved of great value to Koch and which, ever since, have been in daily use everywhere; the micro-chemical differentiation of leukocytes, on which rests the study of the blood for clinical purposes; the development of the methylene blue reaction of living tissues, and the formulation of that unique conception of protoplasmic structure and function on which he based the great sidechain theory which he advanced to explain the reactions in immunity and other phenomena.

What might be termed the second phase of Ehrlich's work concerned investigations in immunity under the guidance of the side-chain conception. No better illustration of the practical usefulness of the imagination in creating a successful working hypothesis can be given than the results achieved by Ehrlich in the field of immunity. Perhaps the usefulness is seen most clearly in the standardization of

1 From the Journal of the American Medical Association. 